\title{
Meaning Construction, Co-construction, and Re-construction in an On-line Reading Club: The Perspective from Discourse Analyses
}

\author{
Ming-Fang Lin (Corresponding author) \\ Dept. of English, National Kaohsiung Normal University, Taiwan (R.O.C.) \\ E-mail: afang904@yahoo.com.tw \\ Ye-Ling Chang \\ Dept. of English, National Kaohsiung Normal University, Taiwan (R.O.C.) \\ E-mail: changy12003@yahoo.com.tw
}

Received: August 11, 2014 Accepted: August 20, 2014 Published: August 21, 2014

doi:10.5296/ijele.v2i2.6176 URL: http://dx.doi.org/10.5296/ijele.v2i2.6176

\begin{abstract}
Many studies have shown the benefits of participating in an on-line reading club for second/foreing language learning. However, few studies investigated the process of club members' constructing meaning from the perspective of discourse analyses. This study aimed to bridge this gap and explored how EFL learners constructed the meaning in an on-line reading club. The data were collected from 11 students' posting general responses to selected issues and peer-responses to club members. The results not only indicated the process of meaning construction, co-construction, and re-construction in the students' responses in the on-line reading club, but also revealed their particular discourse patterns. This paper concluded that the students' participating in the on-line reading club helped them engage in autonomous learning and established the reinforcement between reading and writing.
\end{abstract}

Keywords: on-line reading club, meaning construction, discourse analyses 


\section{Introduction}

Reading is an avenue to the encyclopaedia of world knowledge. Through reading, learners can increase their knowledge and expand their schemata. Thus reading is power (Krashen, 2004). If the act of reading is realized in a learning community, the benefits could be maximized. One of the manifestations of learning communities is a reading club. Previous studies have shown that participation in a reading club can expand learners' understanding of a text, develop higher level thinking skills, and increase independent reading (e.g., Harmon \& Wood, 2001; Whitehead, 2004). In addition, reading clubs can induce positive effects on learners' reading attitude (Whittingham \& Huffman, 2009). As such, reading clubs are facilitative of the development of learners' reading.

However, reading clubs are limited in the following two aspects (Peng, 2010). One is the temporal and spatial limitation. Traditional reading clubs require members to gather in a specific place at a specific time. They are not economic and flexible. The other limitation is that once learners get lower responses in the reading clubs, they are likely to be less motivated. Thanks to the advancement of technology, researchers and educators started to design online reading clubs (hereafter, OLRCs) to enhance learning.

An OLRC is defined as "one of the learning communities in which club memberes can explore selected reading materials and can extend their reading backgrounds and general knowledge together" (Peng, 2010, p.14). Learning in an OLRC is a form of asynchronous computer mediated communication, which can offer many scaffolding features for learning (Wang \& Hannafin, 2005). OLRCs have at least the following three benefits. First, they can be implemented across the boundaries of time and space, and then club members can participate in the OLRC with much flexibility. Second, an OLRC can encourage learners to be engaged in a learning community, in which in-depth discussions and critical reflections can be induced (Peng, 2010). Third, an OLRC can have an effect on changing students' attitude toward reading (e.g., James, 2003). Thus, OLRCs can be widely used to facilitate learning in the instruction of reading.

Reading can expand the readers' schemata and offer bountiful ideas for discussion with others. An OLRC is an ideal forum for reading to provide its own feedback. As Whittingham and Huffman (2009) noted, an OLRC can offer rich interaction for club members to share their understanding of and reflections on a text. If one encounters uncertainties or problems in reading, he/she can discuss with peers and get support from them. Through the repeated interaction, club members can get a sense of belonging and greater motivation to engage further reading for discussion. Eventually, learners can form the habit of independent and autonomous reading.

In an OLRC, participants have to post their responses to the forum. When they compose their responses, they make good use of their background knowledge to comment on the text and then construct their own reflection/meaning. Each member contributes their own reflection and co-constructs the whole meaning. Since the co-constructed meaning is from members of different backgrounds, new ingredients are integrated into the meaning, which is then re-constructed by the OLRC. As Self, Karakirik, Kor, Tedesco, and Dimitrova (2000) argued, 
knowledge is dynamic that can be constructed or reconstructed in pedagogy. Through meaning construction, co-construction, and reconstruction, writing in an OLRC is a process of discovering meanings.

OLRCs receive theoretical supports from three rationales: transaction theory, constructivist pedagogy, and cooperative learning. In the transaction theory, Rosenblatt (1978) argues that the act of reading involves the transaction between the reader and the text, and emphasizes the distinctiveness of each reader because of their different experiences, beliefs, and contexts of reading. To be more specific, a written text does not always provide same meaning for readers. During each act of reading, readers transact with the text by using their individual prior knowledge and belief in constructing meaning. Thus, the act of reading is a dynamic transaction between the reader and the text, and the meaning lies in the readers' interaction with the text. This notion of transaction theory fits into an OLRC (Peng, 2010). Since all the members of an OLRC have different backgrounds, they post pros and cons to the selected issues and questions. Through these different reader responses, they construct the new meaning/knowledge for the learning community.

However, constructivists contend that the sole transaction between the reader and the text is not sufficient for learning (e.g., Palincsar, 1998; Vygotsky, 1978). Instead, they focus on the interdependence of social and individual processes in co-constructing knowledge. Vygotsky (1978) suggests that social interaction with peers and scaffolding from advanced others can maximize the zone of proximal development of learning. Thus, constructivists emphasize social-oriented learninig, which is significant to meaning co-construction in e-learning (Chang, 2009; Krasmsch, 2002).

Learners' social interaction in e-learning closely relates to cooperative learning, which is crucial in an OLRC. According to Johnson and Johnson (1998), in cooperative learning, learners are interdependent with one another, and have to try their best to contribute to the whole group. Through cooperative lerarning, learners can exchange their thoughts to solve the conflicts and tasks. In addition, group members can also provide positive feedback to encourage peers. Harasim (1990) suggests that an OLRC is an effective medium for cooperative learning. In an online reading club, each member is responsible to post their general responses to an issue and peer responses for other members. From individuals' contribution and peers' support, cooperative learning can benefit club members and build positive attitude toward learning.

OLRCs have received the above theoretical supports, and their benefits have been widely explored in the previous studies (e.g., Harmon \& Wood, 2001; James, 2003; Peng, 2010; Wang \& Hannafin, 2005; Whitehead, 2004; Whittingham \& Huffman, 2009). However, few studies examined how club members in OLRCs construct their meaning from the perspective of discourse analyses. Thus, this study aimed to examine how advanced EFL learners construct the meaning in an OLRC.

\section{The Present Study}

Eleven doctoral students majoring in English teaching participated in the present study. They 
enrolled in the course of Topics on Teaching of Reading and were asked to participate in the OLRC-3. In this OLRC, they were scheduled to post their general responses and peer responses to four issues (i.e., situationism in reading clubs in Issue 13, evaluation of reading materials on-line in Issue 16, bridging the gap between reading and writing in Issue 17, and reader responses in Issue 18, see Appendix for the detailed description and guided statement for the four issues) during four weeks. For each issue, each student had to post one general response to the issue and two peer responses to comment others' general responses. This ended up with a corpous of 44 general responses and 88 peer responses. The collected data were qualitatively analyzed in terms of the process of meaning construction and the discourse patterns of the participants' responses.

\section{Results and Discussion}

This study aimed at exploring the students' constructing the meaning in an OLRC through discourse analyses. The results of the participants' general responses and peer responses to the issues are illustrated in section 3.1 and 3.2 respectively.

\subsection{Participants' General Responses to Some Selected Issues}

A general response in OLRC is defined as "a transaction that occurs between a reader and a text" (Peng, 2010, p.7). In OLRC-3, general responses were posted to comment on the prompted questions of some selected issues. This section is to illustrate the participants' general responses in terms of meaning construction, meaning co-construction, and discourse patterns of general responses.

\subsubsection{Meaning Construction}

Meaning construction is "the process for people to synthesize their prior knowledge or social factors into the situation created in contexts and then construct meaning" (Peng, 2010, p.16). In OLRC-3, the participants' general responses were frequently related to meaning construction. Extraction (1) and (2) can demonstrate this process of meaning construction.

(1) I believe that being in a reading club is beneficial for language learners for three reasons. First, language learners get to practice different language skills in a reading club. Second, learners can use the language in an authentic context where they can acquire it more efficiently. Finally, through the discussion and sharing of the materials read by the club members, learners can be exposed to thoughts, ideas, or perspectives different from their own and widen their mind, which then allows them to think more critically. How to implement a reading club in a language class in Taiwan may be challenging due to the generally large size of classes. One possible solution could be holding a reading club outside the regular class hours; however, it requires commitment and dedication on both the teacher's and students' parts. (Student 1's general response to Issue 13)

(2) Both reading and writing get learners engaged in constructing meaning actively. They are similar in several aspects. ... There are two pedagogical implications drawn: first, the more writing tasks are involved in EFL reading instruction, the better students perform in reading comprehension. Second, teachers should select appropriate reading materials and tasks in accordance with each student's unique characteristics. (Student 
7's general response to Issue 17)

In (1), Student 1 synthesized his knowledge of reading clubs and pointed out three reasons for the benefits. Then he further commented on the obstacles of implementing reading clubs in Taiwan according to his observation and teaching experiences. Similarly, in (2), Student 7 used her background knowledge to compare reading and writing, and drew two pedagogical implications for the issue. Both Student 1 and 7 posted good general responses by taking advantage of their schemata, and then constructed their own meanings for the issues. Thus, participating in OLRC-3 engaged learners in reading beyond the lines and meaning construction with critical thinking.

\subsubsection{Meaning Co-construction}

Meaning co-construction refers to the "collaboratively thinking through text ideas" (Berne \& Clark, 2006, p.675). In OLRC-3, each club member contributed his/her general response to the guiding questions of a certain issue to co-construct the meaning for the club. For example, in Issue 13, club members co-constructed the meaning of situationism in reading clubs from different perspectives, such as Student 7's view from pragmatic and sociolinguistic aspect of language use presented in (3), Student 5's point of cooperative learning in (4), and Student 6's argument on reader responses in (5).

(3) Without paying attention to the pragmatic usages of L2, it would result in the breakdown of communication. Language teachers should design appropriate teaching activities for learners. One of the best way is to encourage learners join the reading club, in which they can share their opinions and feelings with each other. (Student 7's general response to Issue 13)

(4) As John Donne has ever put it, " No man is an island, entire of itself; every man is a piece of the continent, a part of the main." ....... By taking part in a reading club, the members in it cooperatively construct the meaning of their very end, in this case, the reading ability. (Student 5's general response to Issue 13)

(5) In a reading club, readers usually share versatile, creative responses to the assigned reading since each of them is equipped with different cultural backgrounds and different development in their multiple intelligences. (Student 6's general response to Issue 13)

In addition to the different theoretical perspectives above, some classmates attended to the advantages and disadvantages of reading clubs. For example, Student 1, as illustrated in (1) earlier, pointed out the benefits of reading clubs, while Student 10 cautioned the reading club about the disadvantages in (6).

(6) Statements made on OLRCs can often be misinterpreted or misleading with no way of immediately questioning or responding to them. The inherent time lag between questions and answers thus prevents a deeper discussion, and topics can easily go off track, resulting in a loss of interest. Additionally, the setting of OLRCs lacks a social component, as communication on online forums is impersonal at best, if not downright anonymous. (Student 10' general response to Issue 13)

Student 10's response above informed club members of the limitations of OLRCs. Similarly, some students pinpointed the obstacles of reading instructions in Taiwan, such as the less 
exposure to L2 authentic inputs mentioned by Student 4 in (7) and the large size of classes by Student 1 in (1).

(7) Students, especially EFL students who usually have less exposure to English context, have to not only learn grammatically correct sentences, but also know how to use the proper language for the right purpose in the right place in the right time as Halliday mentioned. (Student 4's general response to Issue 13)

Some classmates were considerate to provide approaches for solving the problems that they might encounter in teaching, such as using role-plays in teaching dramas by Student 4 in (8) and taking advantage of graded readers to enhance reading comprehension by Student 2 in (9).

(8) It is essential to either use authentic material in reading class to instruct students or have students role-play in the simulated situation for practicing while reading a script of drama. (Student 4's general response to Issue 13)

(9) The new educational policy is intended to enhance American students' reading comprehension. The thought may be applied to L2 learners of English in the Taiwan context. L2 learners in Taiwan can be exposed to different levels of texts, and the graded readers are highly recommended in selecting a reading material. (Student 2's general response to Issue 13)

From the above extractions, club members discussed Issue 13 from different angles with the help of scaffolding and guiding questions. Through the interaction and cooperation in OLRC-3, participants co-constructed the meanings for Issue 13. As Berne and Clark (2005) argued, co-construction and sharing make group members have a more complete understanding of the text. Participating in OLRC-3 definitely expanded members' knowledge toward different issues.

\subsubsection{Discourse Patterns}

Peng (2010) identified six interaction patterns in forum discussions, including inquiry-based discourse, information sharing discourse, reading reflection discourse, analytical evaluation discourse, argumentative discourse, and rapport-building discourse. In the general responses of OLRC-3, club members often demonstrated the combined pattern of [(reading reflection discourse $)+$ (analytical evaluation discourse) + (inquiry-based discourse)]. That is, they tended to reflect on their own experiences and observation, make evaluations for them, and then offered solutions for problems. Student 1's general response to Issue 18 in (10) can best illustrate this combined pattern.

(10) From my teaching experience, students usually feel uninterested or even reluctant when they have to read literature. They feel so for various reasons.

(reading reflection discourse)

Some feel that literature is too difficult and beyond their comprehension: some consider it old-school and outdated: others think it is not relevant to their life.

(analytical evaluation discourse)

As English teachers, we need to find ways to help students realize that literature could be interesting, modern, and relevant to them and in their life. Activities such as discussions, journal entries and logs are good ways to do so. Through these activities. 
students can help each other understand the meaning, knowledge or even wisdom of the literature they are reading.

(inquiry-based discourse)

(Student 1's general response to Issue 18)

In (10), Student 1 first reflected on his teaching experience about students' lower interests in reading literature, pointed out several reasons for the problems, and suggested teaching activities for solutions. The frequent occurrence of this combined pattern can be explained by the club members' backgrounds. Most participants had teaching experiences for years, and thus they could relate the theories to practices. This combined pattern also exhibits club members' critical thinking in constructing the general responses.

In short, analyses on participants' general responses showed the importance of meaning construction and co-construction. In addition, participants often demonstrated the combined pattern of [(reading reflection discourse) + (analytical evaluation discourse) + (inquiry-based discourse)].

\subsection{Participants'Peer Responses to Selected General Responses}

A peer response in OLRC is "a reader's point of view about his/her peers' reflections regarding a text” (Peng, 2010, p.7). Peer responses in OLRC-3 can be used to help club members co-construct meanings for deeper understanding, to show agreement or disagreement, and to build rapport with others. Thus this section illustrates the participants' peer responses to selected general responses in terms of meaning co-construction, discourse pattern, and rapport-building.

\subsubsection{Meaning Co-construction}

Peer responses can help club members co-construct the complete meaning. For example, in (11), Student 5 admitted the benefits of online reading materials, but pointed out his personal perference in reading a paperback book. Peer responses from Student 1 in (12) and Student 8 in (13) further helped Student 5 build a critical thought toward online reading materials.

(11) All these are made possible with the reading materials available online, which indeed remedies the weakness of the traditional way of reading as mentioned in the quote, time and space. However, while thanking to the clever invention of online reading, I have to admit holding a paperback book, enjoying flipping through page after page along with a cup of coffee is still the irreplaceable reading experience for me and, I believe, for many others. (Student 5's general response to Issue 16)

(12) Although convenient and powerful, on-line reading materials still can't completely replace print books. The texture and scent of print books, as well as the act of turning pages, are part of what keeps readers, ancient and modern, attached and fascinated. Besides, the devices on which on-line materials can be done might incur one of the factors impeding the very act of reading - distraction from the wide variety of things readers can do on the devices. (Student 1's peer response to Student 5's general response in Issue 16)

(13) I think [Student 5] is quite correct to play a neutral role in accepting the new on-line reading resources and also a traditional individual reader. But this happy learning 
experience may only happen in summer vacation or winter vacation when there is no study burden, right? In authentic learning environment, I bet that these on-line reading resources may eventually turn out to be "integration" into "instruction journey" (Leu 2004); in that sense, teacher may be so hasty in planning the ideal on-line reading assessments based on the "precise roadmap for instruction" (Leu and et al. upcoming). (Student 8's peer response to Student 5's general response in Issue 16)

In (12), Student 1 reminded Student 5 of the benefits of traditional print books, and suggested the potential drawback of online reading materials. In (13), Student 8 approved Student 5's neutral stance, indicated the reality of teaching in Taiwan, and provided rescources for extending reading. Through the interaction between the general response and peer responses above, Student 5, 1, and 8 co-constructed the meaning for the issue of reading materials online. Furthermore, they even re-constructed the meaning by adding the disadvantages of on-line reading materials and obstacles in teaching. These processes of meaning co-construction and re-construction from peer responses expanded OLRC-3 members' knowledge and enhanced their critical thinking. The learning resources offered by peers also contributed to their autonomous and independent learning.

\subsubsection{Discourse Pattern}

Peer responses can "either be a confirmation of agreement or an argument of disapprovals with their peers" (Peng, 2010, p.7). Most peer responses in OLRC-3 were agreement to peers' general responses. As shown in (14) to (16) below, club members often expressed their agreement in the beginning of their peer responses to confirm others.

(14) I agree with [Student 4] that Taiwanese students have less expsure to authentic English environment. (Student 7's peer response to Student 4's general response in Issue 13)

(15) First of all, I really appreciate the simplied but comprehensive comments on the topic. (Student 6's peer response to Student 5's general response in Issue 17)

(16) I couldn't agree more on [Student 11's] statement that "literature and reading will be so dull if there is only one kind of interpretation." (Student 2's peer response to Student 11 's general response in Issue 18)

However, club members sometimes expressed their disagreement to peers' general responses. Extraction (17) and (18) illustate the typical cases of disapprovals.

(17) For [Student 11], I think I agree with you mostly. But last sentence you mentioned about "with the help of a reading club, readers understand and enjoy the text more fully." Though, the positive advantages from the reading clubs might be many; still, the disadvantage should also be noticed. (Student 8's peer response to Student 11's general response in Issue 13)

(18) I agree with [Student 7's] statements showing that the advantages of online reading materials... Yet, some disadvantages such as fatigue after using computer and distractors from other websites should be taken into consideration. (Student 4's peer response to Student 7's general response in Issue 16)

In (17) and (18), Student 8 and 4 expressed their approval to peers first, followed by contrastive markers 'But' and 'Yet' before their elaboration of disagreement. This discourse 
pattern receives support from the preferred disagreement pattern 'agreement + but + disagreement' in discourse-pragmatic studies (e.g., Chen, 2006; Pomerantz, 1984). The reason for using agreement before disapprovals is to downtone the face-threat of disagreement (Brown \& Levinson, 1987). In addition, this discourse pattern also indicates the club members' critical thinking to help broaden peers' understanding of the issues.

\subsubsection{Rapport-building}

Peer responses can also create social bindings among participants (e.g., Lamy \& Hampel, 2007; Peng, 2010). In the corpous of OLRC-3, the participants also used their peer responses to express their gratitude or reflection on participating in the club. Extraction (19) and (20) can best illustrate their endeavors to build rapport with peers.

(19) I am much obliged to [Student 9] for the supplement of websites. I believe that there should be more useful websites on the Internet in addition to what [Student 9] provided. (Student 4's peer response to Student 9's general response in Issue 16)

(20) It is indeed my joy and luck to learn from the best (everyone) in this "Joy Luck" reading club! (Student 5's peer response to Student 1's general response in Issue 13)

In (19), Student 4 expressed his thanks to Student 9 for the supplement of two useful websites for teaching and learning literature. This statement not only strengthened the relationship between Student 4 and 9, but also encouraged Student 9 to continue to provide useful information for the club. In (20), Student 5's statement of his joy and benefit demonstrated his sense of belonging in participating in OLRC-3. Thus, the function of peer responses in OLRC-3 can enhance the mutual relationship among club members and build a sense of belonging for the learning community.

To recapitulate, this section found that the participants exhibited their process of meaning co-construction and their discourse pattern for disapprovals in peer responses. Also, peer responses can offer opportunities for club memebers to establish their relationship with peers and the group.

\section{General Discussion}

OLRC-3 is a kind of asynchronous computer mediated communication. Participants can post their general responses and peer responses after reading. Since there is no time constraint (Vess, 2005), participants can consult online/offline learning resources for further readings, and compose/rewrite their responses before posting to OLRC-3. This process of consulting resources and rewriting can generate participants' deeper thoughts for discussions (Hiltz, Turoff, \& Harasim, 2007).

As discussed earlier in the general responses of OLRC-3, club members can synthesize what they have read with their background knowledge to construct their own meaning. In addition, they often reflected their teaching experiences, indicated their problems, and then came up with suggestions for solutions. From each member's contribution, the group co-constructed the complete meaning. Similarly, participants responded to peers' general responses by showing agreement or disapprovals with elaborative arguments to co-construct/re-construct 
the meaning. Through the meaning construction and the interaction of meaning co-construction, participants' writing widened their understanding and further reinforced their reading comprehension.

Furthermore, the learning resources from peers' responses and the positive feedback (e.g., the confirmation from others and the sense of belonging from the group) helped engage independent reading for discussions, which in turn could foster the mastery of writing (Whitehead, 2004). Thus, OLRC-3 provides a good context for establishing the reinforcement between reading and writing.

\section{Conclusion}

This study explored how 11 doctoral students constructed the meaning in an OLRC, and then analyzed the participants' general responses and peer responses from the perspective of discourse analyses. The results indicated the process of meaning construction and co-construction in the participants' general responses, which often exhibited the discourse pattern of [(reading reflection discourse) + (analytical evaluation discourse) + (inquiry-based discourse)]. On the other hand, the participants' peer responses allowed the club members to co-construct and re-construct the meaning, and also helped build rapport among them.

This study is limited in the following aspects. First, the limited participants in the present study prevented us from conducting the quantitative analyses. Future studies can include more participants and then examine the distribution of participants' responses in different types of meaning construction and discourse patterns. Second, the issues in OLRC-3 were pre-determined without taking participants' interests into consideratioin. Third, this study only lasted for four weeks with four issues covered. Future studies can extend the span and include more issues of participants' interests. In this way, students' perception toward the participation in OLRCs can also be investigated.

\section{References}

Almasi, J. F., McKeown, M. G., \& Beck, I. L. (1996). The nature of engaged reading in classroom discussions of literature. Journal of Literacy Research, 28, 107-146. http://dx.doi.org/10.1080/10862969609547913

Berne, J. I., \& Clark, K. F. (2005). Making meaning in ninth grade: An exploratory study of peer-led literature discussion. Illinois Reading Council Journal, 33(3), 31-38.

Berne, J. I., \& Clark, K. F. (2006). Comprehension strategy use during peer-led discussions of text: Ninth graders tackle “The Lottery.” Journal of Adolescent \& Adult Literacy, 49, 674-686. http://dx.doi.org/10.1598/JAAL.49.8.4

Brown, P., \& Levinson, S. D. (1987). Politeness: Some universals in language usage. Cambridge, U.K.: Cambridge University Press.

Chang, Y.-L. (2009). Meaning co-construction in a Taiwan-and-Boston video-conferencing project. Paper presented in 2009 International Conference on Multi-Development and Application of Languages and Linguistics. National Cheng Kung University. Retrieved 
January 14, 2014 from http://faculty.ksu.edu.sa/aljarf/Documents/MDALL\%20conference\%2 02009\%20-\%20language\%20and\%20linguistics/01.pdf

Chen, M.-t. (2006). An interlanguage study of the speech act of disagreement made by Chinese EFL speakers in Taiwan. Unpublished master thesis, National Sun Yat-sen University, Taiwan.

Guthrie, J. T. (2001). Contexts for engagement and motivation in reading. Reading Online, 4(8). Retrieve January 12, 2014 from http://www.readingonline.org/articles/art_index.asp? $\mathrm{HREF}=/$ articles/handbook/guthrie/index.html

Harasim, L. M. (1990). Online education: An environment for collaboration and intellectual amplification. In L. Harasim (Ed.), Online education: Perspectives on a new environment (pp.39-66). New York: Praeger Publishers.

Harmon, J., \& Wood, K. D. (2001). The TAB book club approach: Talking (T) about (A) books (B) in content area classrooms. Middle School Journal, 32(3), 51-56.

Hiltz, S. R., Turoff, M., \& Harasim, L. (2007). Online collaborative learning: The history and philosophy of asynchronous learning networks. In R. Andrews \& C. Haythornthwaite (Eds.), Handbook of elearning research. Thousand Oaks, CA.: SAGE Publications.

James, J. (2003). Changing students' attitudes about reading through book clubs. Library Media Connection, 21(7), 30-32.

Johnson, D. W., \& Johnson, R. T. (1998). Learning together and alone: Cooperative, and individualistic learning. Boston: Allyn \& Bacon.

Kramsch, C. (2002). Language acquisition and language socialization: Ecological perspectives. London, UK: Continuum Books.

Krashen, S. D. (2004). The power of reading: Insights from the research. Portsmouth, NH: Heinemann.

Lamy, M. N., \& Hampel, R. (2007). Online communication in language learning and teaching. Basingstoke: Palgrave Macmillan. http://dx.doi.org/10.1057/9780230592681

Palincsar, S. (1998). Social constructivist perspectives on teaching and learning. Annual Review of Psychology, 49, 345-375. http://dx.doi.org/10.1146/annurev.psych.49.1.345

Peng, H.-F. (2010). Discourse analysis of interactive patterns of videoconferences and forum discussions in an online reading club for students from two universities in Taiwan. Unpublished doctoral dissertation, National Kaohsiung Normal University, Taiwan.

Pomerantz, A. (1984). Agreeing and disagreeing with assessments: Some features of preferred/dispreferred turn shapes. In J. M. Atkinson, \& J. Heritage (Eds.), Structures of social action: Studies in conversation analysis (pp.57-101). Cambridge, U.K.: Cambridge University Press.

Rosenblatt, J. (1978). The reader, the text, the poem: The transactional theory of the literary 
work. Carbondale, IL: Southern Illinois University Press.

Self, J., Karakirik, E., Kor, A., Tedesco, P., \& Dimitrova, V. (2000). Computer-based strategies for articulate reflection (and reflective articulation). In Proceedings of international conference on computers in education/ international conference on computer-assisted instruction (pp. 3-12). National Tsing Hua University, Taiwan.

Vess, D. (2005). Asynchronous discussion and communication patterns in online and hybrid history courses. Communication Education, 54(4), 355-364. http://dx.doi.org/10.1080/03634520500442210

Vygotsky, L.S. (1978). Mind in society: The development of higher psychological processes. Cambridge, MA: Harvard University Press.

Wang, F., \& Hannafin, M. J. (2005). Design-based research and technology-enhanced learning environments. Educational Technology Research \& Development, 53(4), 5-23. http://dx.doi.org/10.1007/BF02504682

Whitehead, N. (2004). The effects of increased access to books on student reading using the public library. Reading Improvement, 41(3), 165-175

Whittingham, J. L., \& Huffman, S. (2009). The effects of book clubs on the reading attitudes of middle school students. Reading Improvement, 46(3), 130-136.

\section{Appendix}

\begin{tabular}{|c|c|}
\hline Issue & Guided statement/description \\
\hline $\begin{array}{l}\# 13 \text {. Situationism in } \\
\text { reading clubs }\end{array}$ & $\begin{array}{l}\text { 1. People have to learn to use the right language for the right } \\
\text { purpose in the right place in the right time in } \\
\text { pragmatics. So people can acquire appropriate language } \\
\text { when using the language (Halliday, 1978). } \\
\text { 2. In a reading club, readers can share their responses to the } \\
\text { assigned reading selections with their club members and get } \\
\text { feedback, either positive or negative. So language is the } \\
\text { instrument of social cooperation and mutual participation } \\
\text { (Karakirik, et al., 2000). } \\
\text { 3. Like energy, knowledge can provide its own feedback when } \\
\text { it is used in thought mapping in a reading club (Chang, } \\
\text { 2002). }\end{array}$ \\
\hline $\begin{array}{l}\# 16 . \quad \text { Evaluation of } \\
\text { reading } \quad \text { materials } \\
\text { on-line }\end{array}$ & $\begin{array}{l}\text { 1. Reading materials on-line remedy the weakness of printed } \\
\text { reading materials across the time and the space boundaries. } \\
\text { 2. Two basic principles for choosing appropriate reading } \\
\text { materials on-line for readers include the criteria of the } \\
\text { instructional design and the interface design. } \\
\text { 3. The copy right of the reading material on-line has been } \\
\text { challenged nowadays. }\end{array}$ \\
\hline $\begin{array}{l}\# 17 \text {. Bridging the gap } \\
\text { between reading and } \\
\text { writing }\end{array}$ & $\begin{array}{l}\text { 1. Reading practice and writing practice reinforce one another. } \\
\text { 2. A person usually plays duel rules, including a writer and a } \\
\text { reader, when revising his writing piece. } \\
\text { 3. Many activities combine reading and writing together, such }\end{array}$ \\
\hline
\end{tabular}


as a reading cycle, a writer cycle, guestbook on-line or discussion on-line.

\#18. Reader responses 1. Reader-response criticism started with I.A. Richards's discussions of emotional response in the 1920s or with the work of D. W. Harding and Louis Rosenblatt in the 1930s. The formal discussion of the theory started from Walker Gibson in 1950 (Tompkins, 1980)

2. A (good) reader usually actively participated in the production of textual meaning (Iser, 1978)

3. Teachers should take students' personal and emotional responses to the work into account and avoid giving definitive interpretations to the text (Liaw, 1997).

4. Activities such as discussions, journal entries, and literature logs can be sued to help students develop their personal view of literature (Lay, 1995; McGee, 1992).

\section{Copyright Disclaimer}

Copyright for this article is retained by the author(s), with first publication rights granted to the journal.

This is an open-access article distributed under the terms and conditions of the Creative Commons Attribution license (http://creativecommons.org/licenses/by/3.0/). 